\title{
On species related to Elachista pollutella Duponchel (Lepidoptera, Elachistidae), with descriptions of four new Palaearctic species
}

\author{
Lauri Kaila
}

\begin{abstract}
Kaila, L. 2011: On species related to Elachista pollutella Duponchel (Lepidoptera, Elachistidae), with descriptions of four new Palaearctic species. - Entomol. Fennica 22: 129-139.

The taxonomy of the relatives of Elachista (Aphelosetia) pollutella Duponchel, 1843 is clarified. The following species are described as new: Elachista jubarella sp. n. from Russian Caucasus, Elachista rutjani sp. n. from Russia: South Ural and Tuva, and Ukraine, Elachista enochra sp. n. from Turkmenistan, and E. cretula sp. n. from Kazakhstan and Turkmenistan. E. pollutella, previously only known from Central and Southern Europe, is recorded for the first time from Asian part of Russia in Altai Mts. and Mongolia. The identity of Elachista ilicrina Falkovitsh, 1986 is discussed.

L. Kaila, Finnish Museum of Natural History, Zoological Museum, FI-00014 University of Helsinki; E- mail: lauri.kaila@helsinki.fi
\end{abstract}

Received 21 March 2011, accepted 29 April 2011

\section{Introduction}

Elachista pollutella Duponchel, 1843 is a large species of Elachista (Elachistidae: Elachistinae). It is characterized by white wings with ochreous or brownish irroration. The wingspan ranges from 10 to $14 \mathrm{~mm}$, males often being larger than females. It is widely distributed in Central and Southern Europe from France in the west to Volga area in Russia and Crimea in Ukraine in the east (Budashkin \& Sinev 1991, Anikin et al. 2007, Kaila 2009).

E. pollutella belongs to the subgenus Aphelosetia of Elachista Treitschke, 1833 (Kaila 1999). The interrelationships within Aphelosetia are unclear; the matter has been discussed by Albrecht \& Kaila (1997), Kaila (1997, 2007) and Kaila \& Junnilainen (2002). In this paper the classification of Kaila (1997) is followed, and Elachista pollutella is considered to belong to the $E$. bedellella group due to the modification of the juxta that characterizes this group (Kaila 2007). On the basis of the structure of both male and female genitalia, E. pollutella is likely related to $E$. catalana Parenti, 1978 which, with its closest relatives, is discussed by Kaila (2011).

As being characteristic in appearance and genitalia (see Traugott-Olsen 1990), E. pollutella has not called for closer taxonomic scrutiny, but examination of recent materials has shown that there are further, undescribed species involved that are attributable to the Elachista pollutella complex. Four of them are described as new in this paper.

\section{Material and methods}

This paper is based on material obtained from the following collections:

Finnish Museum of Natural History, Zoological Museum, University of Helsinki, Finland (L. 


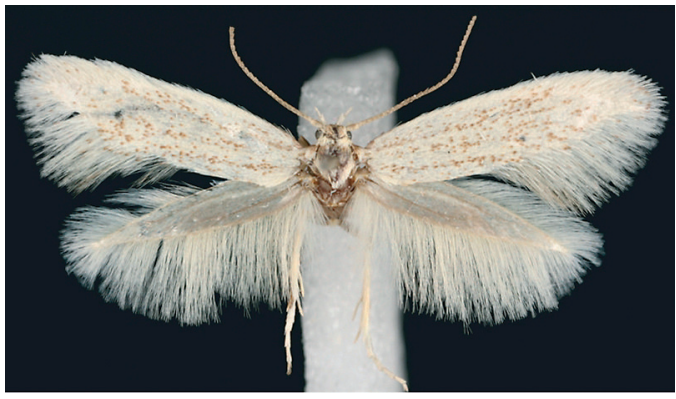

Fig. 1. External appearance of Elachista pollutella Duponchel, male (Italy, Trieste; Coll. TLMF).

Kaila) (MZH); Tiroler Landesmuseen Ferdinandeum, Innsbruck (P. Huemer) (TLMF), The Zoological Museum, University of Copenhagen, Denmark (O. Karsholt) (ZMUC), Russian Academy of Sciences, St. Petersburg (S. Sinev) (ZIN), Siberian Branch of the Russian Academy of Sciences, Novosibirsk (V. Dubatolov) (SZMN) and Zoological Museum, Kiev National Taras Shevchenko University, Ukraine (O. Bidzilya) (ZMKU); private collections of Kari and Timo Nupponen (Espoo, Finland), and Vadim Zolotuhin Ulyanovsk, Russia).

Terminology of anatomical structures follows Traugott-Olsen \& Schmidt Nielsen (1977) and Kaila $(1997,1999,2007)$. The names of new species are nomina in apposition.

\section{Taxonomy}

\subsection{Elachista pollutella Duponchel}

Figs. 1, 2, 11, 12, 21

Elachista pollutella Duponchel, 1842 [1843]: 486.

Material studied. Austria: Rechnitz, Ga'genhügel, 350 m, 5.V.1984 H. Habeler leg. (L. Kaila prep. 4199, Coll. TLMF); Germany: Germ. mer., Staudinger, Coll. Tengström $1 \lesssim 1$ (L. Kaila prep. 430, Coll. MZH); Italy: Trieste 2.-10.IV.1951 1 ๙ Pinker leg. (Traugott-Olsen prep. n. A.26.5.90, Coll. TLMF); Trieste, Mte. Montasio, 2.-10.IV.1951 1 o Pinker leg. (Coll. TLMF); Prov. Trieste, Sistione, 80 m, 9.IV.1985 2 đ 4 \& K. Burmann \& G. Tarmann leg. (L. Kaila prep. 4200, 4201, 4204, 4205, Coll. TLMF); Mte Baldo, Ferrara, 900-1,300 m, emg. IV.1968 1 ठ K. Burmann leg. (L. Kaila prep. 4202, Coll.

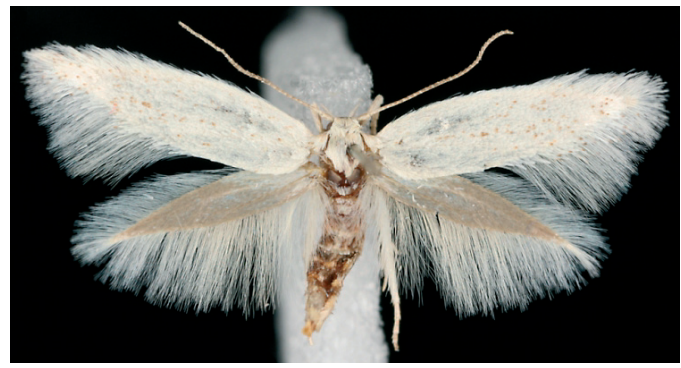

Fig. 2. External appearance of Elachista pollutella Duponchel, female (Italy, Trieste; Coll. TLMF).

TLMF); L. da Garda, Pai, 100 m, 25.IV.1965 1 ภ K. Burmann leg. (L. Kaila prep. 4203, Coll. TLMF); Mongolia: Tov Aimak 48 $22^{\prime} \mathrm{N} 106^{\circ}$ 18'E, 1,100 m, 18.-23.VI.1997 1 ठ Yu. M. Marusik leg. (L. Kaila prep. 3943, Coll. MZH); Russia: Ul'yanovsk obl., Beketovka, Veshkayma distr., 100 km W Ul'yanovsk, 30.IV.1994 2 §ै V. V. Zolotuhin, A. \& V. B. Isajev leg. (Coll. Zolotuhin); Akulovka, Nikolaevka distr. $150 \mathrm{~km}$

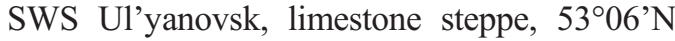
47²9'E 16.-17.V.1998 6 ठ [no collector mentioned] (Coll. Zolotuhin); Solovchiha / Shihan, 150 km SWS Ul'yanovsk, 10.-11.V.1997 1 ઈ 1 q V. V. Zolotuhin leg. (Coll. Zolotuhin); Vjazovka, 8 km S., Radishchevo distr., 168 km S Ul'yanovsk, 5250’N 48¹8'E 4.-5.V.2002 3 ㅇ V. B. Isajeva leg. (Coll. Zolotuhin); Saratov obl., Chvalinsk distr., Chvalinsk 6.-11.V.2000 2 ô V. Anikin leg. (Coll. Zolotuhin); Altai Mts. $51^{\circ} 00$ 10'E 85³5-45'E Sarlyk region, 2,000 m, 24.VI.2000 3 ऽ 4 ๆ T. \& K. Nupponen leg. (L. Kaila prep. 3239, 3243, 4063, 4064, 4065; Coll. Nupponen, MZH); Ukraine: Crimea, Karadagh 24.IV.1991 1 ふૈ, 3.V.1991 2 ふ, 4.V.1991 5 ふ, 7.

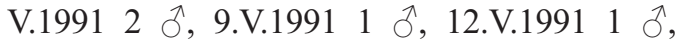
13.V.1991 2 ふૈ, 14.V.1991 2 ふૈ, 9.V.1992 1 ठૈ, 10.V.1992 1 ふ, 15.IV.1993 2 ふ, 17.V.1993 1 ठૈ,

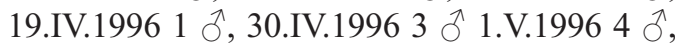
2.V.1996 5 ภ, all Yu. Budashkin leg. (L. Kaila prep. 2204, 3240, 4058, 4059, Coll. MZH); Donetskaya obl. Novoazhovskiy raion Chomutovskaya N. P. 7.V.1996 1 ภ 1 ,

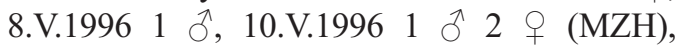
19.V.1996 1 ð 2 古 (MZH), 24.IV.2001 1 ठ A. Bidzilya leg. \& Coll.

Diagnosis. Elachista pollutella is the largest of the species in this complex. It is white, forewings dusted with brownish scales that are often 
arranged as lines along veins. Their presence distinguishes it readily from $E$. ilicrina and $E$. jubarella sp. n. In E. rutjani sp. n. the forewings are pale yellow, variably dusted with grey irroration not arranged along veins. The forewings of E. cretula sp. n. are dirty ochreous white with irregular grey dusting. The male genitalia of $E$. pollutella are somewhat variable. The extremes of the variation is shown in Figs. 11 and 12; there has not been detected any clear geographic pattern regarding genital structure, so all populations from western Europe to Mongolia are here considered conspecific. The male genitalia of $E$. pollutella differ from those of E. rutjani $\mathbf{s p .} \mathbf{n}$. by the smaller size of the uncus lobes and the broader digitate process of $E$. pollutella as compared to $E$. rutjani sp. n., from those of $E$. jubarella $\mathbf{s p .} \mathbf{n}$. by the broader valva and digitate process of $E$. pollutella as compared to $E$. jubarella $\mathbf{s p .} \mathbf{n}$.; from $E$. ilicrina by the broader valva with straight termen of cucullus in E. ilicrina as compared to $E$. pollutella. The phallus of E. cretula sp. n. is broader than in the other species. Unfortunately the females of the species other than E. pollutella are presently unknown. When identifying the species of this complex, the species related to $E$. catalana Parenti should also be taken into account; they are treated by Kaila (2011).

Biology. E. pollutella inhabits exposed habitats, and the larva has been reported to feed on Elymus hispidus (Opiz) Melderis (Poaceae) (Szöcs 1968, 1971).

Distribution. Widely distributed in Central Europe (Kaila 2009), also recorded in southern parts of European Russia and Ukraine: Crimea. New to Siberian Russia and Mongolia.

\subsection{Elachista jubarella sp. $n$.}

Figs. 3, 4, 13, 14

Type material. Holotype $\sigma^{\top}$ : Russia $43^{\circ} \mathrm{N} 43^{\circ} \mathrm{E}$ Kabardino-Balkarsk N. P. 35 km SE Mt. Elbrus, alpine meadow, 2,500 m, 15.VII.1990 J. Jalava leg., L. Kaila prep. 4057 (MZH). Paratype: $1 \hat{\sigma}$ with the same collecting data as in the holotype (L. Kaila prep. 390, MZH).

Diagnosis. Elachista jubarella sp. n. is close to E. pollutella. Externally it is distinguished by the unicolorous white forewings and the smaller

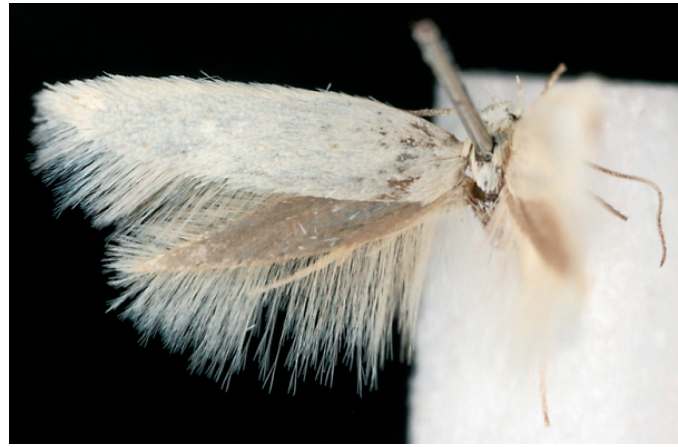

Fig. 3. External appearance of Elachista jubarella sp. n., ${ }^{\widehat{T}}$ holotype.

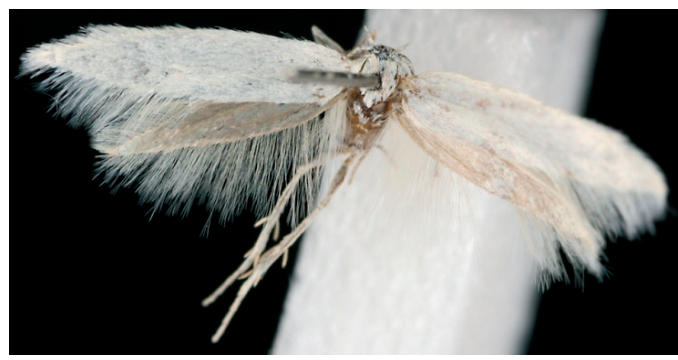

Fig. 4. External appearance of Elachista jubarella sp. n., $\widehat{O}$ paratype.

size than in E. pollutella. The male genitalia differ by the shape of the valva and digitate process, which both are longer and narrower in $E$. jubarella sp. n. than in E. pollutella. The same features distinguish it also from other species treated in this paper.

Description. Wingspan $12 \mathrm{~mm}$. Length of labial palpus 1.1-1.2 times diameter of head, white. Head, neck tuft, scape, pedicel and base of flagellum of antenna white, flagellum otherwise pale grey. Thorax white. Fore femur grey, legs outwardly otherwise pale brown, inwardly pale ochreous. Forewing unicolorous chalky white with concolorous fringe scales; basal third of costa narrowly grey. Hindwing dark grey above, with paler yellowish fringe scales; underside of forewing dark grey, fringe scales white, underside of hindwing pale grey.

Male genitalia. Uncus lobes 1.5 times longer than wide, distally rounded, with a few setae laterodistally, separated by V-shaped incision. Gnathos relatively large, as long as uncus lobes, elongate, parallel-sided, three times as long as 


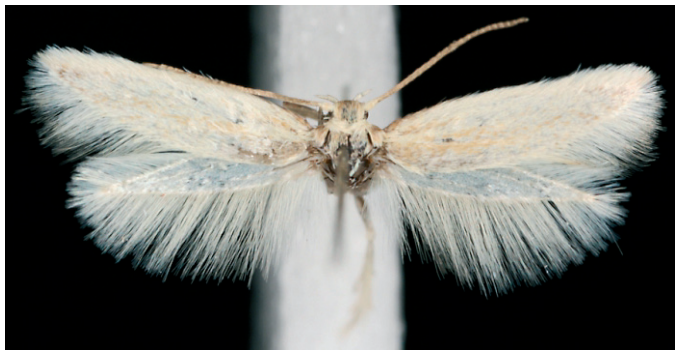

Fig. 5. External appearance of Elachista rutjani sp. n., $\lesssim$ holotype.

wide, tapered towards pointed apex. Valva 5.5 times as long as wide at its widest point in the middle and in cucullus, costa convex medially, emarginated at about 3/4 length; sacculus basally somewhat bulbous, medially weakly concave, distally joins cucullus without distinct border; distal margin of cucullus rounded. Digitate process narrow, parallel-sided, distally blunt and setose, extending to $1 / 4$ length of valva. Mesial margin of juxta lobe convex, meeting distal margin without an angle, distal margin mesially somewhat produced, without setae, lateral margin concave; laterally produced and joined to valval process. Median plate of juxta with welldeveloped, tongue-shaped, dorsally projected lobe. Vinculum short and broad, V-shaped. Phallus 0.6 times the length of valva, medially its width $1 / 7$ of its length, slightly bent; nearly parallel-sided; coecum rounded; distal opening extended to distal 3/4 of phallus. No cornuti present.

Female genitalia. Unknown.

Biology. Unknown. The specimens were found in active flight at dusk in an alpine meadow.

Distribution. Russia: Western Caucasus.

Remarks. This species was erroneously reported as E. habeleri Traugott-Olsen by Kaila \& Jalava (1994). E. habeleri is now considered a synonym of $E$. argentella (Clerck) (Huemer 2000).

\subsection{Elachista rutjani sp. $\mathrm{n}$.}

Figs. 5, 6, 15, 16

Type material. Holotype $\sigma^{\top}$ : Russia, S. Ural, Orenburg district, Pokrovka vill., Schibendy valley 10.V.2005 K. Nupponen leg., L. Kaila prep.

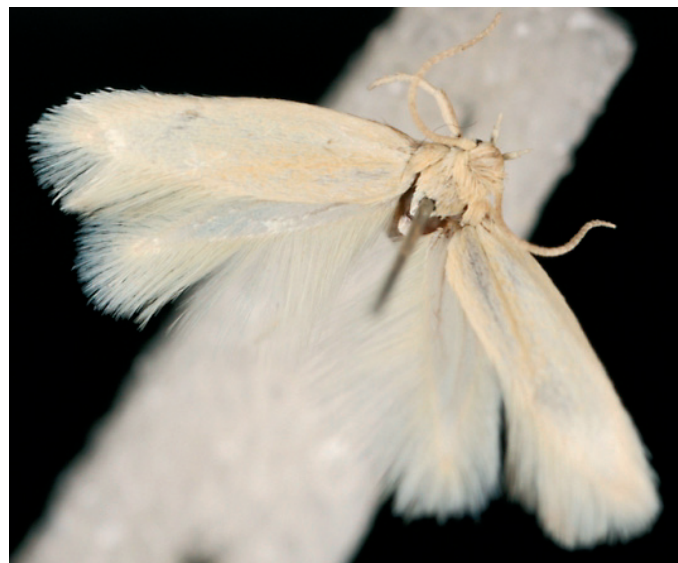

Fig. 6. External appearance of Elachista rutjani sp. n., o paratype.

5293, in Coll. Nupponen. Paratypes (5 ठ): 1 ઈ with the same collecting data as in the holotype, except the date 11.V.2005 (L. Kaila prep. 4836, in MZH); Russia, Lower Volga region, Prov. Volgograd, distr. Pallasovka, lake Elton, loc. Tschernavka, 3.-8.V.2004 1 o E. Rutjan leg. (Coll. ZMKU); Tuva rep. 50¹6’N 945', $1,250 \mathrm{~m}, 25 \mathrm{~km} \mathrm{~W}$ Erzin, steppe/stony slopes, 7.11.VI.1995 1 ๙ J. Jalava \& J. Kullberg leg., L. Kaila prep. 1653, Coll. MZH; Ukraine, Donetskaya oblast, Novoachovskiy raion, steppe, 24.4. 20012 đ E. Rutjan leg. (L. Kaila prep. 4436, in Coll. ZMKU, L. Kaila prep. 4426 in Coll. MZH).

Diagnosis. Short labial palpi distinguish this species from all other species in this complex. In the male genitalia the very large and rounded the uncus lobes are characteristic. They are more reminiscent of some species in the Elachista pollinariella complex, from which it is distinguished by the presence of the tongue-shaped, dorsally directed pocket in the median plate of the juxta lobes that the species of E. pollinariella complex are lacking. The square juxta lobes are larger in E. rutjani sp. n. than in any other species in this complex.

Description. Wingspan 7.5-9 mm. Labial palpus 0.7 times as long as diameter of head, below fuscous, above white. Head, neck tuft, tegula, thorax, scape and pedicel of antenna white or yellowish white, flagellum brownish grey with bronzy sheen. Legs outwardly whitish grey, tarsal segments greyish brown. Forewing and hindwing above varying from white to yellow, to some ex- 
tent irrorated with brownish-tipped scales; with concolorous fringe scales, forewing below pale grey with white fringe, hindwing below white with concolorous fringe scales.

Male genitalia. Uncus lobes very large, somewhat longer than wide, evenly rounded, with a few setae laterodistally, separated by narrow incision. Gnathos elongate, oval, broadest medially, three times as long as wide, tapered towards apex. Valva four times as long as wide at its widest point in the middle and in cucullus, costa weakly convex medially, slightly emarginated at about $3 / 4$ length; sacculus straight, distally joins cucullus without distinct border; distal margin of cucullus nearly straight, cucullus not bent towards costa. Digitate process small, narrow, parallel-sided, distally blunt and setose, extending to $1 / 6$ length of valva. Mesial margin of juxta lobe straight, meeting the nearly straight distal margin at a right angle, without setae, lateral margin concave; laterally produced and joined to valval process. Median plate of juxta with well-defined, tongueshaped, dorsally projected lobe. Vinculum short and broad. Phallus half the length of valva, its width medially less than $1 / 10$ of its length, slightly bent; broadest at coecum, otherwise nearly parallel-sided; coecum rounded; distal opening extended to distal $3 / 4$ of phallus. No cornuti present.

Female genitalia. Unknown.

Biology. The specimens collected in South Ural were swept from vegetation in a limestone steppe before sunset.

Distribution. Russia: southern Ural and Lower Volga region; Ukraine.

\subsection{Elachista enochra sp. $n$.}

Figs. 7, 8, 17, 18

Holotype $\widehat{\jmath}$. Turkmenistan, Central part of the Kopetdagh Mts., $15 \mathrm{~km} \mathrm{~W}$ from Firyuza (now Poevryuze), Mt. Dushak, [2,100 m a.s.1., mountain xerophytous belt, Juniperus tree savanna-like forest], by light trap, 1.V.1987 V. Dubatolov leg. (L. Kaila prep. 4025. Paratypes: 2 o with the same data as in the holotype (L. Kaila prep. 1689, 4021, 1 त in SZMN, 1 o in MZH).

Diagnosis. E. enochra sp. n. is a unicolorous creamy white species. The genitalia are close to those of E. rutjani $\mathbf{s p .} \mathbf{n}$., but differ by the smaller

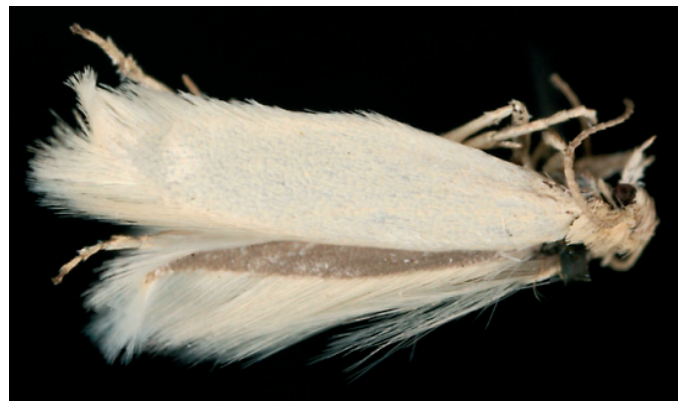

Fig. 7. External appearance of Elachista enochra sp. n., $\widehat{o}$ holotype.

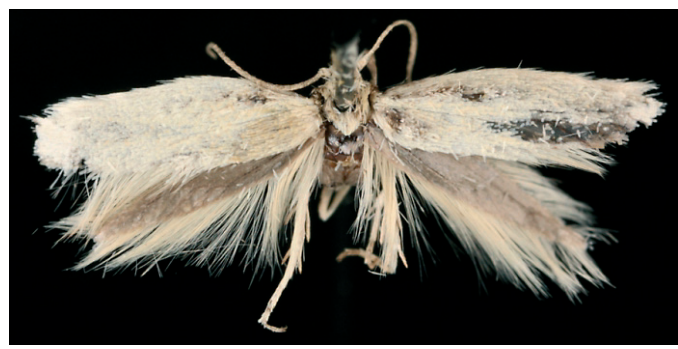

Fig. 8. External appearance of Elachista enochra sp. n., ồ paratype.

uncus lobes and juxta lobes. E. rutjani sp. n. has significantly shorter labial palpi than $E$. enochra sp. n. E. cretula $\mathbf{s p .}$ n. has suffused wings, and its phallus is broader than in E. enochra sp. n. See also remarks below.

Description. Wingspan. 12.5-13 mm. Length of labial palpus 1.1-1.2 times diameter of head, pale yellow, second segment fuscous below. Head, neck tuft, scape and pedicel of antenna pale yellow, intermixed with brown scales. Flagellum grey, slightly serrate in distal third. Thorax pale yellow. Fore femur grey, legs outwardly otherwise pale brown, inwardly pale ochreous. Forewing ground colour unicolorous pale yellow with concolorous fringe scales; basal third of costa narrowly grey. Hindwing dark grey above, with paler yellowish fringe scales; underside of both wings dark grey, fringe scales yellowish white.

Male genitalia. Uncus lobes twice longer than wide, somewhat tapered towards rounded apex, with a few setae laterodistally, separated by narrow incision. Gnathos elongate, oval, broadest medially, four times as long as wide, tapered towards pointed apex. Valva about 3.5 times as long 


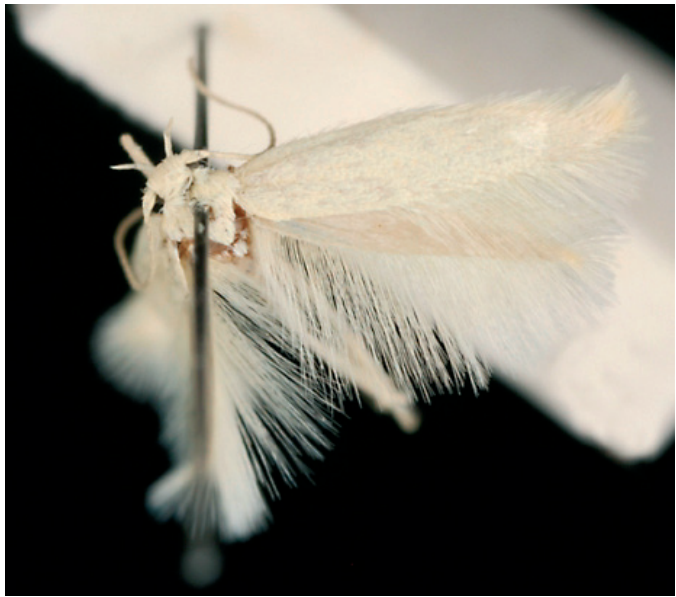

Fig. 9. External appearance of Elachista ilicrina Falkovitsh, ô holotype.

as wide at its widest point in the middle and in cucullus, costa weakly convex medially, slightly emarginated at about 3/4 length; sacculus straight or medially slightly concave, distally joins cucullus at a right angle; distal margin of cucullus straight, cucullus slightly bent towards costa. Digitate process small, broad, parallel-sided, distally blunt and setose, extending to $1 / 5$ length of valva. Mesial margin of juxta lobe somewhat convex, meeting the convex distal margin at an obtuse angle, without setae, lateral margin concave; laterally produced and joined to valval process. Median plate of juxta with well-defined, tongue-shaped, dorsally projected lobe. Vinculum short and broad. Phallus half the length of valva, its width medially $1 / 10$ of its length, straight; broadest at coecum, gradually tapered towards apex; coecum rounded; distal opening

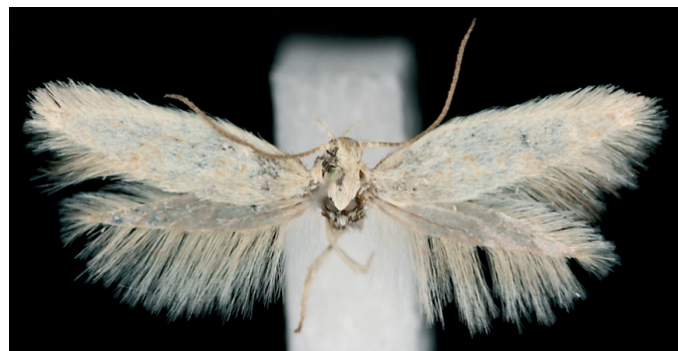

Fig. 10. External appearance of Elachista cretula sp. n., $\widehat{O}$ holotype.

extended to distal $2 / 3$ of phallus. No cornuti present.

Female genitalia. Unknown.

Biology. Unknown.

Distribution. Turkmenistan.

Remarks. Falkovitsh (1986) described Elachista ilicrina, a pure white species, on the basis of one specimen from Kyzylkum, now in Uzbekistan. The male genitalia of the type specimen appear similar to E. enochra sp. n. The genital slide of the holotype of E. ilicrina could not unfortunately be located for study (S. Sinev, pers. comm.), but the original illustration, in association with the original description, indicates that $E$. enochra sp. n. is not conspecific with the holotype of E. ilicrina. Notably, the median plate of the juxta of E. ilicrina is devoid of the characteristic dorsally projected median lobe, indicating that it is closer to E. pollinariella Zeller than E. pollutella complex. The specimens described and depicted in this paper as E. enochra sp.n. are significantly larger than the holotype of E. ilicrina, their head is suffused with brown scales, and the hindwings are grey; the holotype of E. ilicrina

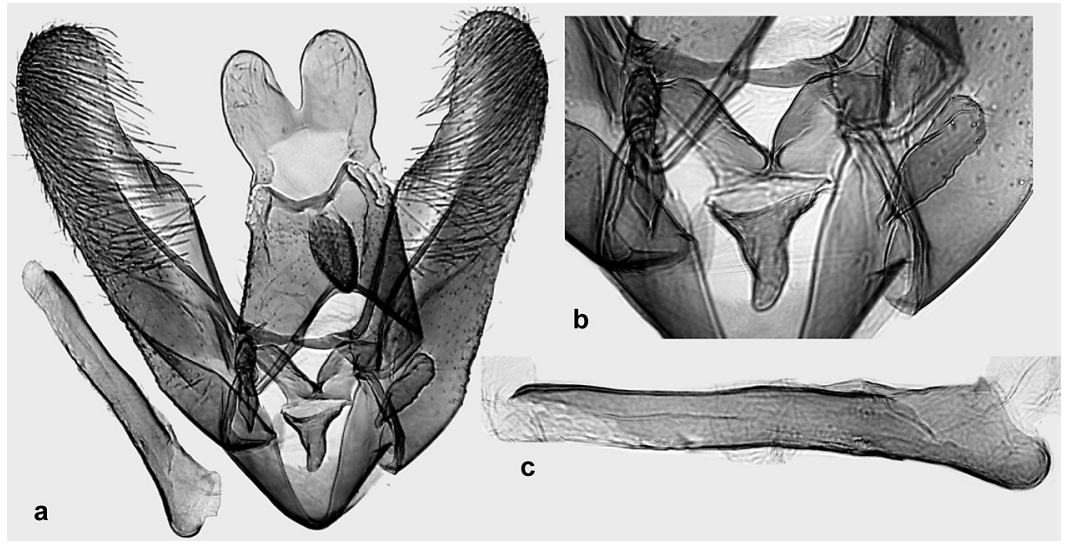

Fig. 11. Male genitalia of Elachista pollutella Duponchel (Italy, Trieste, L. Kaila prep. 4201, Coll. TLMF). - a. general image, - b. juxta and digitate process enlarged, - c. phallus enlarged. 
Fig. 12. Male genitalia of Elachista pollutella Duponchel (Russia, Altai, L. Kaila prep. 3239 , coll. Nupponen). - a. general image, $-b$. juxta and digitate process enlarged, $-\mathrm{c}$. phallus enlarged.

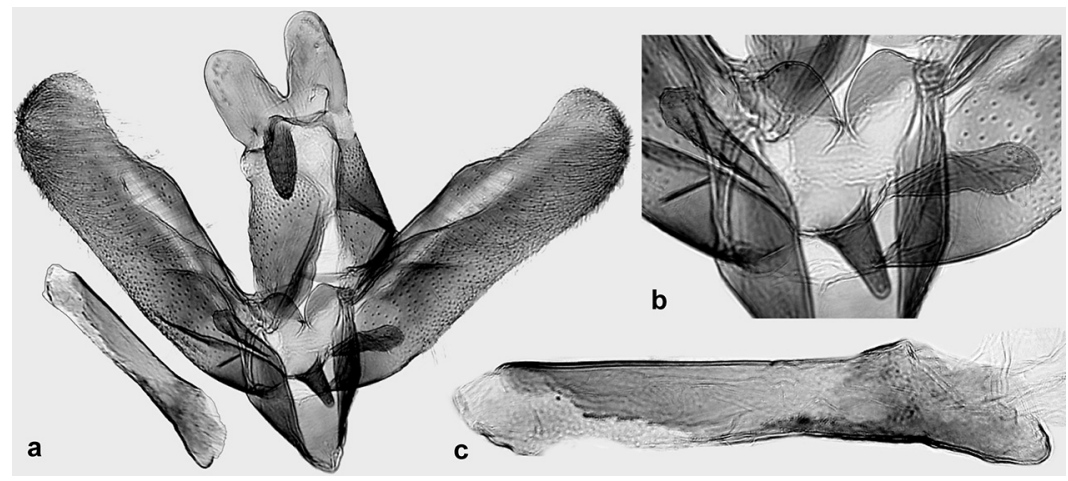

Fig. 13. Male genitalia of Elachista jubarella sp. n. holotype (L. Kaila prep. 4097). - a. general image, - b. juxta and digitate process enlarged, - c. phallus enlarged.

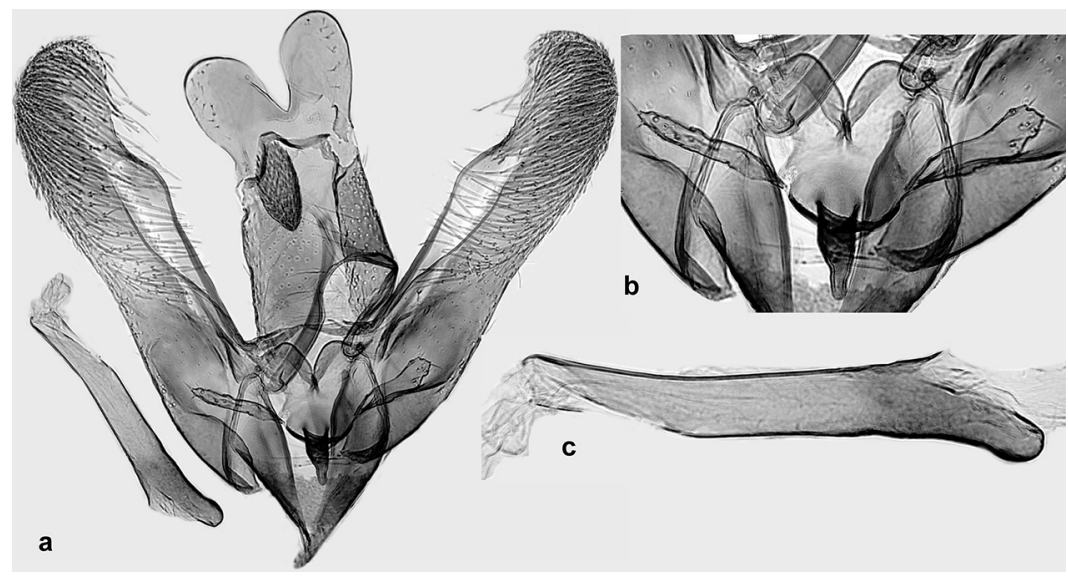

Fig. 14. Male genitalia of Elachista jubarella sp. n. paratype (L. Kaila prep. 390). -a. general image, - b. juxta and digitate process enlarged, -c. phallus enlarged.

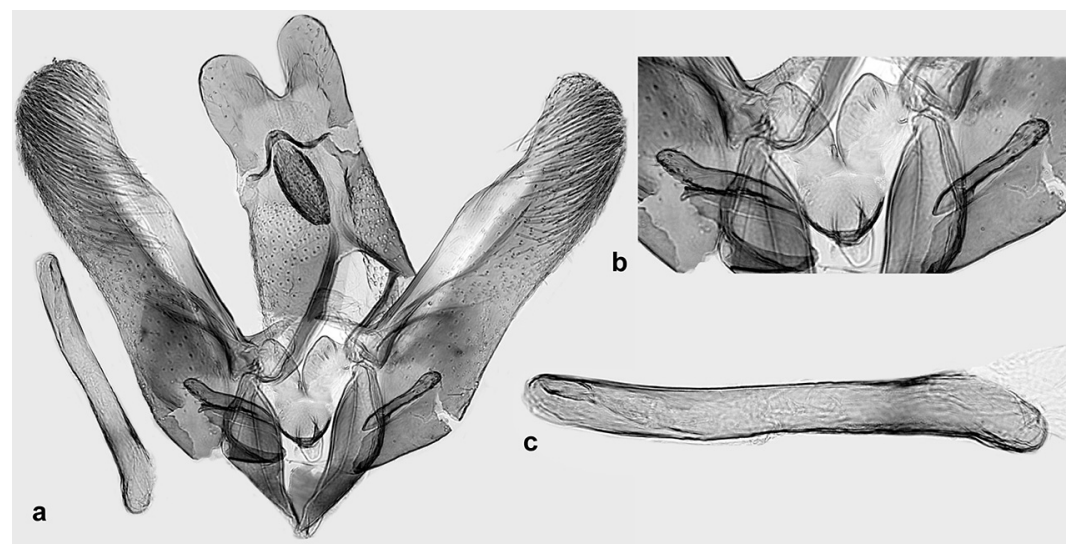

has the wingspan about $9 \mathrm{~mm}$, its head is unicolorous creamy white, and its hindwings are nearly white (Fig. 9).

\subsection{Elachista cretula sp. $\mathbf{n}$.}

Figs. 10, 19, 20

Type material. Holotype $\widehat{\jmath}$ : S. Kazakhstan $42^{\circ} 27^{\prime} 51^{\prime \prime} \mathrm{N} 67^{\circ} 41^{\prime} 17^{\prime}$ 'E NE Kyzylkum desert, 220 m, 40 km W. Koksarai village, 2.V.2010 K. Nupponen leg. (L. Kaila prep. 5268, Coll.

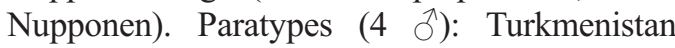
38²9'49'N 5706'29” E W. Kopet-Dagh Mts., 405 m, 5 km W Archman village, 4.IV.2011 K. Nupponen \& R. Haverinen leg. (L. Kaila prep. 5329, Coll. Nupponen); S. Turkmenistan, Kyzyl- 

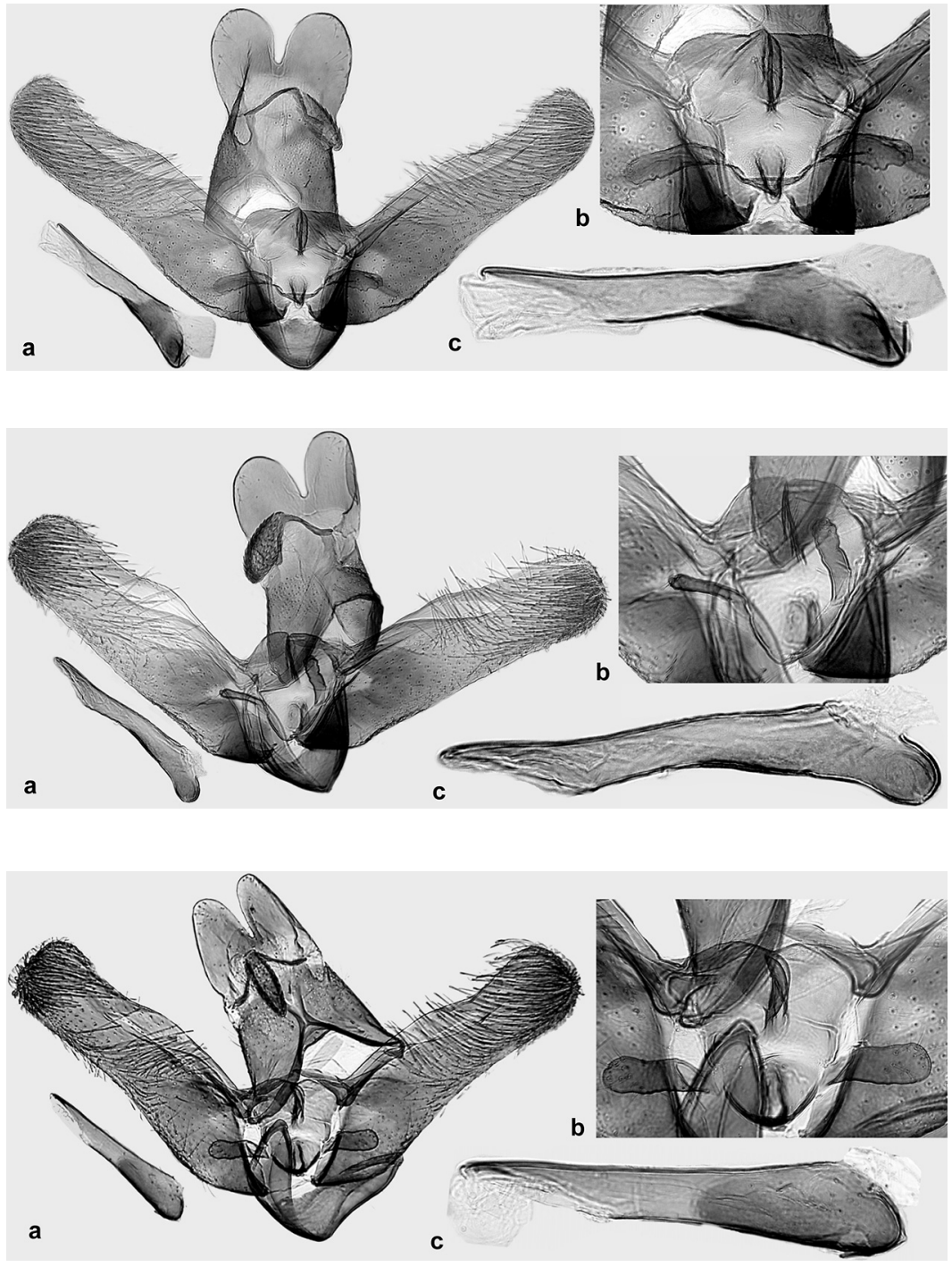

Fig. 15. Male genitalia of Elachista rutjani sp. n. holotype (L. Kaila prep. 5293). - a. general image, $-b$. juxta and digitate process enlarged, - c. phallus enlarged.

Fig. 16. Male genitalia of Elachista rutjani sp. n. paratype (L. Kaila prep. 4436). - a. general image, $-b$. juxta and digitate process enlarged, - c. phallus enlarged.

Fig. 17. Male genitalia of Elachista enochra sp. n. holotype (L. Kaila prep. 4025). - a. general image, $-b$. juxta and digitate process enlarged, - c. phallus enlarged. kum, nr Basar-denye Vill., 2 6.IV.1991 V. V. Dubatolov leg. (L. Kaila prep. 1686, 4788, in Coll. SZMN); Turkmenistan, Kugitang Mts., nr Basar-denye Vill., 1,720 m, 10.V.1991 1 † V. V. Dubatolov \& V. Zinchenko leg. (L. Kaila prep. 1688, in Coll. MZH).

Diagnosis. Elachista cretula $\mathbf{s p .}$. externally somewhat resembles E. pollutella, but it is smaller. The forewing ground colour is dirty yellowish white with irregular dusting by pale brown scales. The male genitalia of these species differ by the broader phallus of E. cretula $\mathbf{s p .}$. . as compared to E. pollutella, and by the tongueshaped median lobe of the median plate of the juxta, which is much larger and occupying most of the median plate in E. pollutella, while it is small in E. cretula sp. n. E. cretula $\mathbf{s p . ~ n . ~ h a s ~}$ somewhat smaller but longer uncus lobes than $E$. rutjani sp. n.; the phallus is broader, and its distal opening is shorter than in E. rutjani sp. $\mathbf{n}$.

Description. Wingspan 10.5-11.5 mm. Length of labial palpus 1.1-1.2 times diameter of head, white above and somewhat fuscous below. Head, neck tuft, scape, pedicel and base of flagellum of antenna creamy white, dusted with ochreous grey scales, flagellum dark grey. Thorax dirty white. Fore femur grey, legs outwardly otherwise pale brown, inwardly pale ochreous. 
Fig. 18. Male genitalia of Elachista enochra sp. n. paratype (L. Kaila prep. 4021). -a. general image, - b. juxta and digitate process enlarged, -c. phallus enlarged.

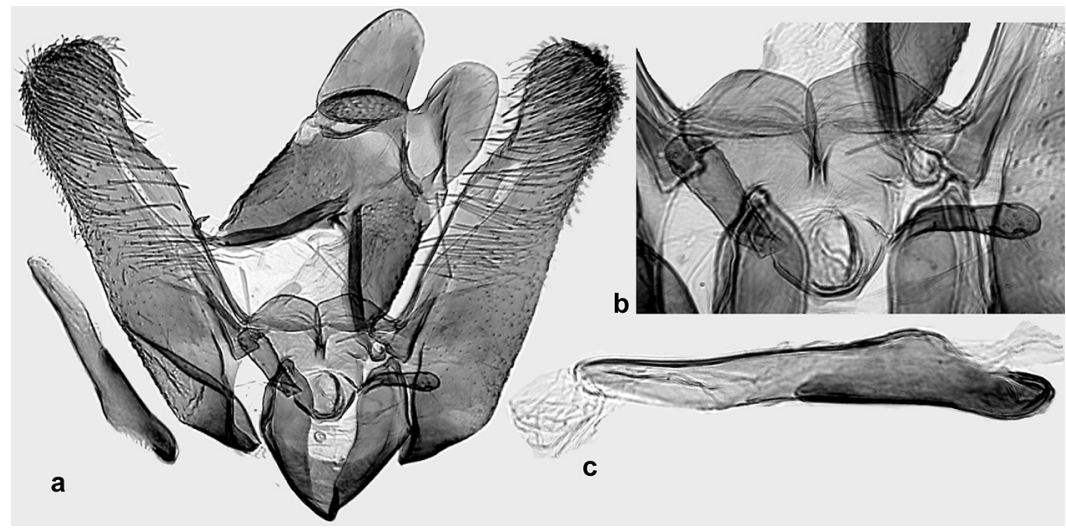

Fig. 19. Male genitalia of Elachista cretula sp. n. holotype (L. Kaila prep. 5268). - a. general image, - b. juxta and digitate process enlarged, - c. phallus enlarged.

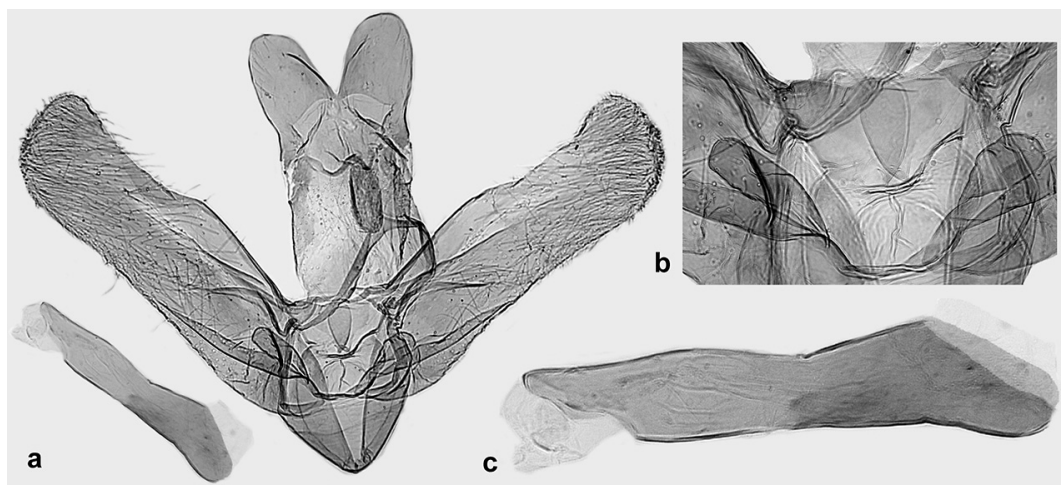

Fig. 20. Male genitalia of Elachista cretula sp. n. paratype (L. Kaila prep. 4788). - a. general image, $-b$. juxta and digitate process enlarged, - c. phallus enlarged.

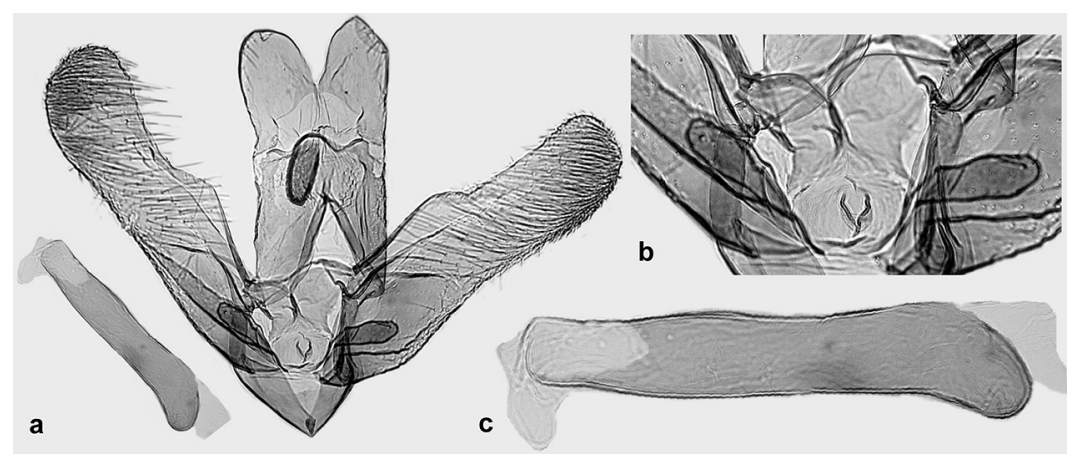

Forewing creamy white, suffused with pale grey and brown scales, fringe scales creamy white; basal third of costa narrowly grey. Hindwing grey above, with paler yellowish grey fringe scales; underside of forewing grey, fringe scales creamy white, underside of hindwing white.

Male genitalia. Uncus lobes large, twice longer than wide, distally rounded, with a few setae laterodistally, separated by V-shaped incision. Gnathos elongate, parallel-sided, three times as long as wide, tapered towards blunt apex. Valva four times as long as wide at its widest point in the middle and in cucullus, costa convex medially, slightly emarginated at about $3 / 4$ length; sacculus basally somewhat bulbous, otherwise straight, distally joins cucullus without distinct border; distal margin of cucullus nearly straight. Digitate process small, broad, parallel-sided, distally blunt and setose, extending to $1 / 6$ length of valva. Mesial margin of juxta lobe straight, meeting distal margin without an angle, without setae, lateral margin concave; laterally produced and joined to 


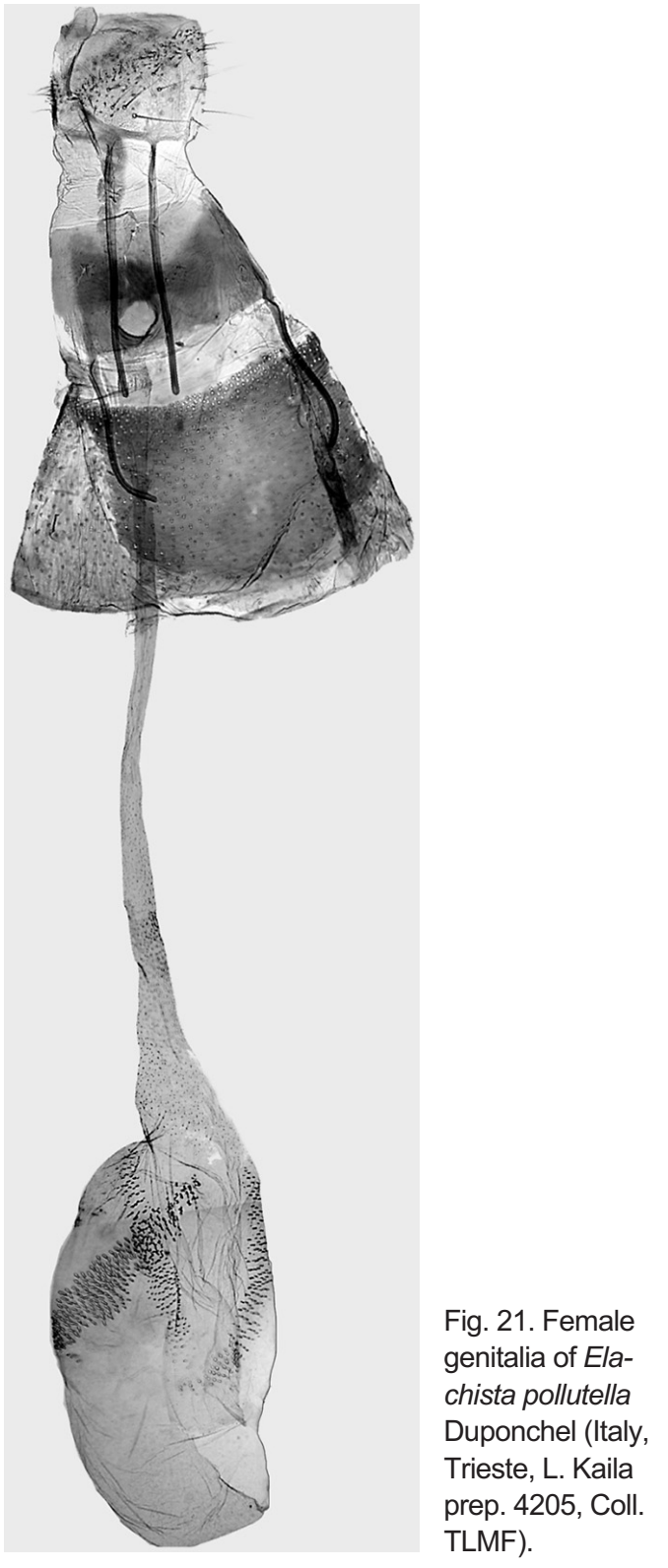

valval process. Median plate of juxta with short, tongue-shaped, dorsally projected lobe. Vinculum short and broad. Phallus $3 / 5$ of the length of valva, medially its width $1 / 7$ of its length, slightly bent; nearly parallel-sided; coecum rounded; distal opening extended to distal $5 / 6$ of phallus. No cornuti present.

Female genitalia. Unknown.

Biology. Unknown.

Distribution. Kazakhstan, Turkmenistan.

\subsection{Elachista chionella Mann, 1861}

Elachista chionella Mann, 1861: 193. Type locality: Turkey: Amasia. Lectotype in ZMHB, designated by Schmidt Nielsen \& Traugott-Olsen (1978).

Material examined. Turkey: Aksehir $30 \mathrm{~km}$ SW Sultan Daglari, 1,200-1,500 m, 2.-3.V.1996 27 đ 3 ㅇ Nupponen \& J. Junnilainen leg. (4 ㅅ 1 q in MZH), 20.V.2005 2 Ј. Junnilainen leg. (LK prep 5085, in coll. Junnilainen and MZH); $30 \mathrm{~km}$ SW Aksehir 28.IV.1998 2 § 2 q J. Tabell leg. (MZH); 35 km SW Aksehir, Cetince, 1,200 m, 9.-13.V.2000 3 त 2 ㅇ J. Junnilainen leg. \& Coll.

Diagnosis. Elachista chionella Mann is externally characterized by the silky white forewings. The male genitalia are characteristic as lacking the digitate process. The species has been adequately redescribed by Schmidt Nielsen \& Traugott-Olsen (1978). It is distributed to Turkey.

Acknowledgements. I would like to express my gratitude for the loan of material and/or valuable information to $\mathrm{O}$. Bidzilya (Ukraine, Kiev), V. Dubatolov (Russia, Novosibirsk), P. Huemer (Austria, Innsbruck), K. Nupponen (Finland, Espoo), S. Sinev (Russia, St. Petersburg) and V. Zolotuhin (Ulyanovsk, Russia). Pekka Malinen helped with habitus photographs.

\section{References}

Albrecht, A. \& Kaila, L. 1997: Variation of wing venation in Elachistidae (Lepidoptera: Gelechioidea): methodology and implications to systematics. - Systematic Entomology 22: 185-198.

Anikin, V. V., Sachkov, S. A., Zolotuhin, V. V. \& Sinev, S. Yu. 2007: "Fauna Lepidopterologica Vologo-Uralensis" 150 years later: changes and additions. Part 14. Elachistidae. (Insecta, Lepidoptera). - Atalanta 38: 395-402.

Budashkin, Yu. I. \& Sinev, S. Yu. 1991: Grain-mining moths (Lepidoptera, Elachistidae) of the Karadagh Reservation. - Entomologicheskoe Obozrenie 70: 574-585.

Duponchel, P.-A.-J. 1843: — In: Godart, J.-B 1842[-44]: Histoire naturelle des Lépidoptères ou Papillons de France (Nocturnes, Supplement aux Tomes quatrième et suivants). Supplement 44, 534 pp., pls. 51-90. Paris.

Falkovitsh, M. I. 1986: (Lepidoptera of Kuldzhuktan mountains and adjacent plateau.) — In: Fauna Lepidoptera USSR. - Trudy Vsesoyuznogo Entomologicheskogo Obshchestva 67: 131-186. [In Russian.] 
Huemer, P. 2000: Additions and corrections to the fauna of butterflies and moths of Austria (Lepidoptera). - Beitraege zur Entomofaunistik 1: 39-56.

Kaila, L. 1997: A revision of the Nearctic species of Elachista s. l. II. The argentella group (Lepidoptera, Elachistidae). - Acta Zoologica Fennica 206: 1-93.

Kaila, L. 1999: Phylogeny and classification of the Elachistidae s.s. (Lepidoptera: Gelechioidea). - Systematic Entomology 24: 139-169.

Kaila, L. 2007: A taxonomic revision of the Elachista bedellella (Sircom) complex (Lepidoptera: Elachistidae: Elachistinae). — Zootaxa 1629: 1-25.

Kaila, L. 2009: Fauna Europaea: Elachistidae. Fauna Europea: Lepidoptera, Moths. - Fauna Europaea version 2.2. [www document] URL http://www. faunaeur.org

Kaila, L. 2011: Revision of species related to Elachista catalana Parenti (Lepidoptera, Elachistidae: Elachistinae), with descriptions of two new species. - Entomologica Fennica 22: 85-96.

Kaila, L. \& Jalava, J. 1994: Elachista adelpha sp. n., E. coeneni titanella ssp. n., and other Elachistidae (Lepidoptera) from North Caucasus. - Entomologica Fennica 5: 97-102.
Kaila, L. \& Junnilainen, J. 2002: Taxonomy and identification of Elachista cingillella (H.-S.) and its close relatives (Lepidoptera: Elachistidae), with descriptions of two new species. - Entomologica Fennica 13: 167188.

Schmidt Nielsen, E. \& Traugott-Olsen, E. 1978: Elachistidae (Lepidoptera) described by O. Staudinger, J. Mann and C. Mendes. — Entomologist's Gazette 29: 5-16.

Szöcs, J. 1968: Some unknown data concerning miners (Lepidoptera). - Acta zoologica hungarica 14: 225231.

Szöcs, J. 1971: Die natürlichen Futterpflanzen der Schmetterlingsraupen, II. - Folia entomologica hungarica 24: 443-464.

Traugott-Olsen, E. 1990: Descriptions of four new species of Elachistidae (Lepidoptera) and diagnoses of Elachista pollutella Duponchel, 1843 and Elachista constitella Frey, 1859. — SHILAP Revista de lepidopterologia 18: 273-285.

Traugott-Olsen, E. \& Schmidt Nielsen, E. 1977: The Elachistidae (Lepidoptera) of Fennoscandia and Denmark. - Fauna Entomologica Scandinavica 6: 1-299. Klampenborg, Denmark. 